\title{
Life After Death in a Chinese Community
}

\author{
MOHD HAFIZOL AMIN BIN RAMLI, NUR AMELIA BINTI MAZLAN, SITI AIDA BINTI AZMI \\ MUHD SARJI BIN AWANG BULAT \& PARVEEN KAUR* \\ Faculty of Social Sciences and Humanities, Univesiti Malaysia Sarawak, 94300 Kota Samarahan, \\ Sarawak, Malaysia \\ *Corresponding author: sspkaur@unimas.my
}

\begin{abstract}
According to San Fillipo (2006), death is not the end of one's existence, but rather than a transition from one life to another. However, it is different based on how the society and individuals see the concept of death itself and how they understand about it. Thus, this article aims to explore the understanding of the relationship between culture and religion that become their identity in terms of death and life after. Qualitative approach is adopted for this study. Indeed, interview and empirical observation were used to obtain quality data.
\end{abstract}

Keywords: Buddhism, Chinese, community, culture, life after death, Taoism

Copyright: This is an open access article distributed under the terms of the CC-BY-NC-SA (Creative Commons Attribution Non Commercial Share Alike 4.0 International License) which permits unrestricted use, distribution, and reproduction in any medium, for non-commercial purposes, provided the original work of the author(s) is properly cited.

\section{INTRODUCTION}

Death in general can be defined as a separation of the soul from the body. To Dietrich (1997: p.19), death is a natural stage in the repeating cycle of renewal. While in the medical terms, death can be defined as a phenomenon when a person's heart stopped beating and that is called as "clinical death" (Wasmuth, 1969). From humans to plants and animals as living creatures, death is a situation that will definitely happen to the living things. The concepts of death to humans is associated with the belief system or religion. It exists in almost all religions in the world. Death from the other side can be seen as a phase of life where most of religion belief death is not the ending of life. As stated by San Fillipo (2006) death is not the end of one's existence but rather than a transition from one life to another. However, it is different based on how the society and individuals see the concept of death itself and how they understand about it.

In relation to the concept of death and life after death, different religions have a different conviction about what would happen to humans after they die. Death and the life after often compromise with culture of the society that combines with their belief system. Culture plays an important role in all society that becomes their identity. An example that can be seen on the relationship between culture and religion in some society is through the grave. Every religion has a distinctive way of burial when someone dies. In this case, the grave is an important element of the cultural attachment that distinguishes one society to another in terms of their belief and religion. Furthermore, cultural attachment on the grave such as symbols, rituals, practices and customs has a relation to the life after death in certain society and religion.

Regarding to the issue of the life after death, this research is conducted on the Chinese community that embrace Buddhism and Taoism. Chinese community has a unique belief towards the life after death. The cultural attachment of the grave especially symbols in Buddhism and Taoism Chinese community manifested the life of dead person in the second life. Besides that, practices, rituals and offerings to the ancestors believed to have the connection between the living and the dead person's life. Therefore, this study is aimed to make the understanding of the relationship between culture and religion that become their identity in terms of death and life after.

"All the deceased's papers were burnt in the brick oven [at the cemetery] ...Food was provided and set out on the newly made grave so that the departed might not go hungry ... (T] he dead was given a coin to hold in the mouth, with which to pay admission to heaven" (Lund, 1947 as cited in Briggs, 2002:p.8). 
As stated above, it is the ritual and practices of the Chinese community that embrace Buddhism and Taoism regarding the life after death. The buried ceremony in every single religion has a unique identity. This identity has been used by their followers to represent their death. Today this culture has been forgotten. This situation might be caused by the modernity. Grave is used as symbolic of people after death. To the Buddhism and Taoism Chinese community, grave is the connection within this world and second world. However, most of the people in capitalism society nowadays are less interested to know about religion, ritual and death in Chinese Buddhism and Taoism community.

\section{Research Questions}

This research was conducted to answering the research question as stated below:

1. What is the meaning of the death for the Chinese Community?

2. Why they have different status after death?

3. Why they have different symbol at their grave?

4. How important is respecting the dead?

\section{Research Objectives}

This research consists several objectives to be achieved which is:

1. To identify the meaning of death for the Chinese Community.

2. To determine about their status after death.

3. To analyze the different symbols that that exist at the grave.

4. To determine the important of respecting the dead.

Buddhism has their deep roots in Chinese history. Many people think that the origin of Buddhism came from China. According to Fan (1956), the scholar believe that Buddhism first became known in China about 100 B. C., when the Chinese had their first contact with the outside world, and that was when the first Buddhist classic appeared and most monasteries were built about $60 \mathrm{~A}$. D. Other than that, Buddhism influenced many aspects of the daily life of the people and played an important part in the spiritual life of the nation (Fan, 1956, p. 2). It is because, for them whatever they do in their life will affect their future life whether in Nirvana or their rebirth.

According to Hartz (1993), Taoism is one of the two great philosophical and religious traditions that originated in China. While Palmer (1991) state that Taoism is not an easy faith or philosophy to understand. It is because Taoism religion have multiple meaning and language to understand. For Mong (2006), he preferred to call Taiosm as Laoism, the teaching of Laocious, pure and unadulterated, that have moulded Chinese culture side by side with the teachings of Confucius. It is because Lacious lived at the same time with Confucius around the sixth century B.C. E (before the Common Era). In Chinese community, the word tao means "the way" which is understood as the way of nature (Hartz, 1993, p. 8). Additionally, Hartz (1993) also stated that Taoist see the cycles of nature and the constant change in the natural world as earthly signs of a great and universal force.

For the Taoism ritual, they do the ancestor rites and this is an important ritual in Chinese culture which places a high value on family and continuity (Hartz, 1993, p. 81). The descendants or family will come to the memorials for their ancestors before celebrating a festival meal to welcome the New Year. A simple ancestor memorial might include the burning of incense and a libation, or ritual pouring, of wine at the family altar, as well as prayers in which family members share the events of the day with their ancestor and ask the ancestor's blessing (Hartz, 1993, p. 81). It is because, if the ancestor blessed their memorial, the ancestor will send a sign to give the family to proceed the ritual. For the ancestor rites, it requires the family to arrange the home altar in a special way with incense in the middle including flowers and candles on both side. Hartz (1993) also stated that other than burning the joss stick, foodstuff including meat, beans, fruit, soup, cookies, rice, tea and wine are offered in a prescribed order. It is different with the Chinese Buddhism in Malaysia where their rituals are not same with the other religious as stated by Tan (2011):

"Makanan daging tidak disembah kepada dewa-dewi agama Buddha, sama seperti daging khinzir tidak disembah kepada dewa-dewi yang asalnya orang Melayu”.

Although the ritual between Buddhism and Taoism might be different, but there are similar celebration for the festivals. Based on Hartz (1993), in celebrating the ritual or feast, both Buddhists and Taoists do the same, even in the Buddhist celebraton, Taoist priest perform the ritual part of the ceremony and summon the souls of the dead. 


\section{MATERIALS \& METHODS}

In this study, the qualitative approach is adopted by using interview and empirical observation regarding the issue that is being studied. This is one of the important parts in this study to enable the research question to be answered and allow the research objective of this study to be achieved. Besides that, ethics in conducting this research has been taken into consideration.

Interview method and observation were used in this study is to obtain in-depth information. Two types of respondents were interviewed which was the grave keeper and the Chinese community that was conducting the Cheng Beng ceremony. The purpose of interviewing the grave keeper is to get some information regarding the grave especially symbols on the Chinese grave that gives a meaning about the life after death. Besides that, interview conducted to the Chinese community that practice Cheng Beng ceremony is to obtain information about their belief in death and the life after.

This study also emphasizes ethics in conducting research. A letter of permission to conduct the study is prepared before going to the study area. Consents were also seeked from respondents. Permission of taking pictures of graves and ritual and recording the interview session as well as their offering practices were given emphasis to this study.

\section{RESULTS \& DISCUSSION}

Based on our fieldwork and desktop research, there consist differences between symbol and ritual practiced by Chinese Community nowadays and during the past.

Although, based on our observation and research we see it as assimilation because certain rituals are almost the same but in different way. While they differ in many things, they share the same fundamental confidence in reincarnation. Well, actually each religion has a unique approach to such belief in the same way that each highlights a distinct way of life.

When talk about reincarnation, in Taoism they belief to maintain of the eternal soul. Instead if dying they must know and understand the concept of shift to another life and lives by until their goal is accomplish which is normally based on natural flow of the universe. The Taoism does care very much about balance, but one of the most important aims of it was to prolog people's lives by In our fieldwork, we interviewed 8 respondents whereas 5 of them are Taoism and 3 of them are Buddhism. We divided it into for sub-section which is following our objectives.

\section{The Meaning of Death for the Chinese Community \\ "Mati adalah suatu perkara yang kita perlu takut dan setiap masyarakat Cina mempunyai kepercayaan terhadap hidup selepas mati."}

According to respondent's statement, most of them believe in life after death. Six out of eight respondents said that they have learned the meaning of death from their ancestor or family and two out of eight respondents learnt from education institution and their surroundings.

\section{Status After Death}

Buddhism - almost all our respondents said that the status of death depends on family economy and the willingness of their family members to spend the money for the decoration of the grave and so on.

Taoism - normally based on economy of the family. If their family generations are rich they will build the big grave for their family member. It depends on the size of the grave lot and all the style of decoration. Some of the Taoist said they believe that the higher the grave, the dead people are closer with their deity. Well, some of the modern people believe it still depends on their economy. The higher the grave from the ground, it will cost more. Even though to buy the grave lot is really costly, so that's why certain grave is located really at the bottom of the hill because their family member cannot afford it. So, their status basically depends on their family economy. Below are pictures that show the different status based on their size of grave lot. 

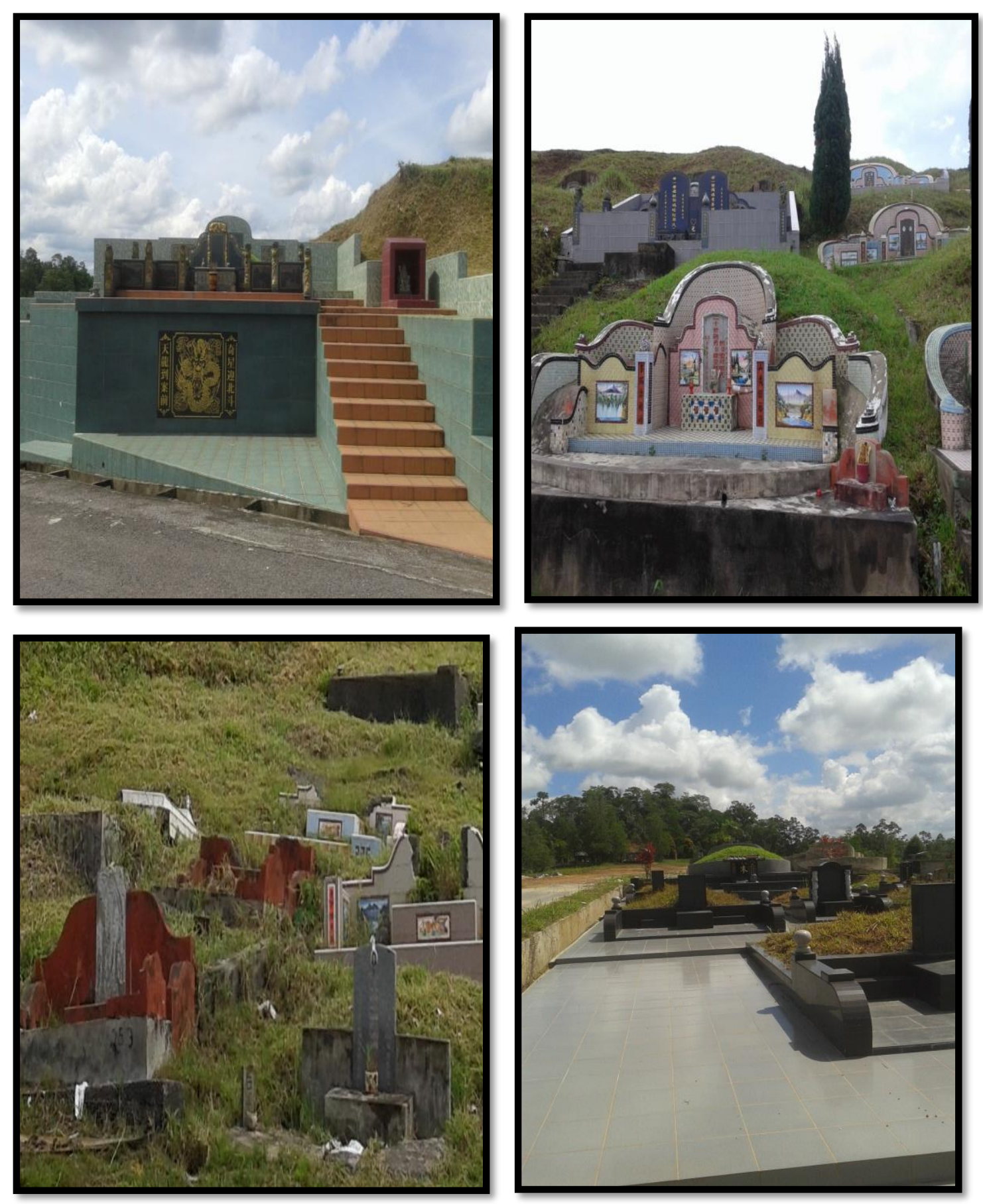

Figure 1. Pictures of cemeteries. 


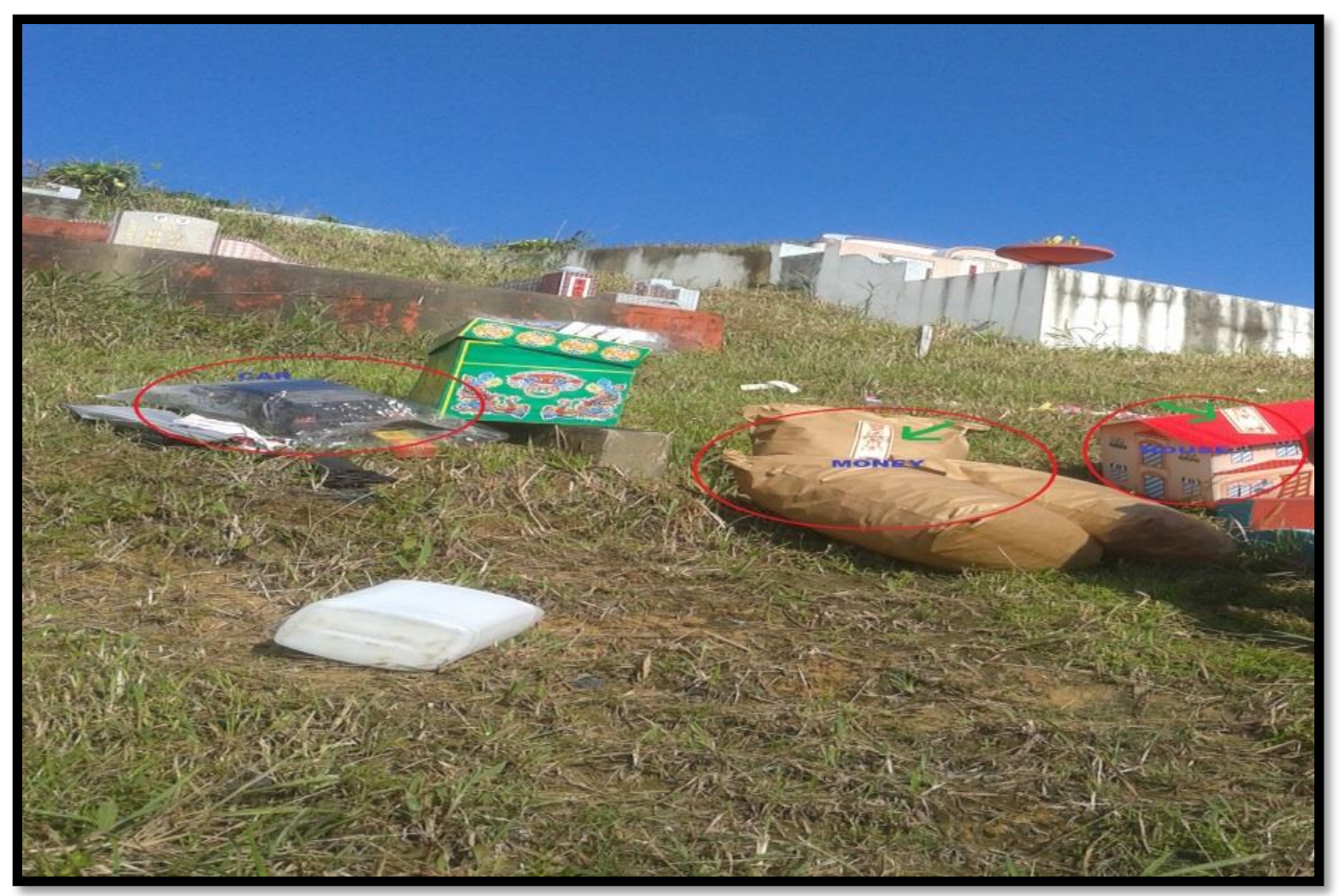

Figure 2. Tools at cemetery.

For the offering, the Chinese Taoism brings the necessity tools for their ancestor such as car, house, and money and so on to use in the other world. However, they also argue when they bring the modern tools that maybe their ancestor did not know how to use them.

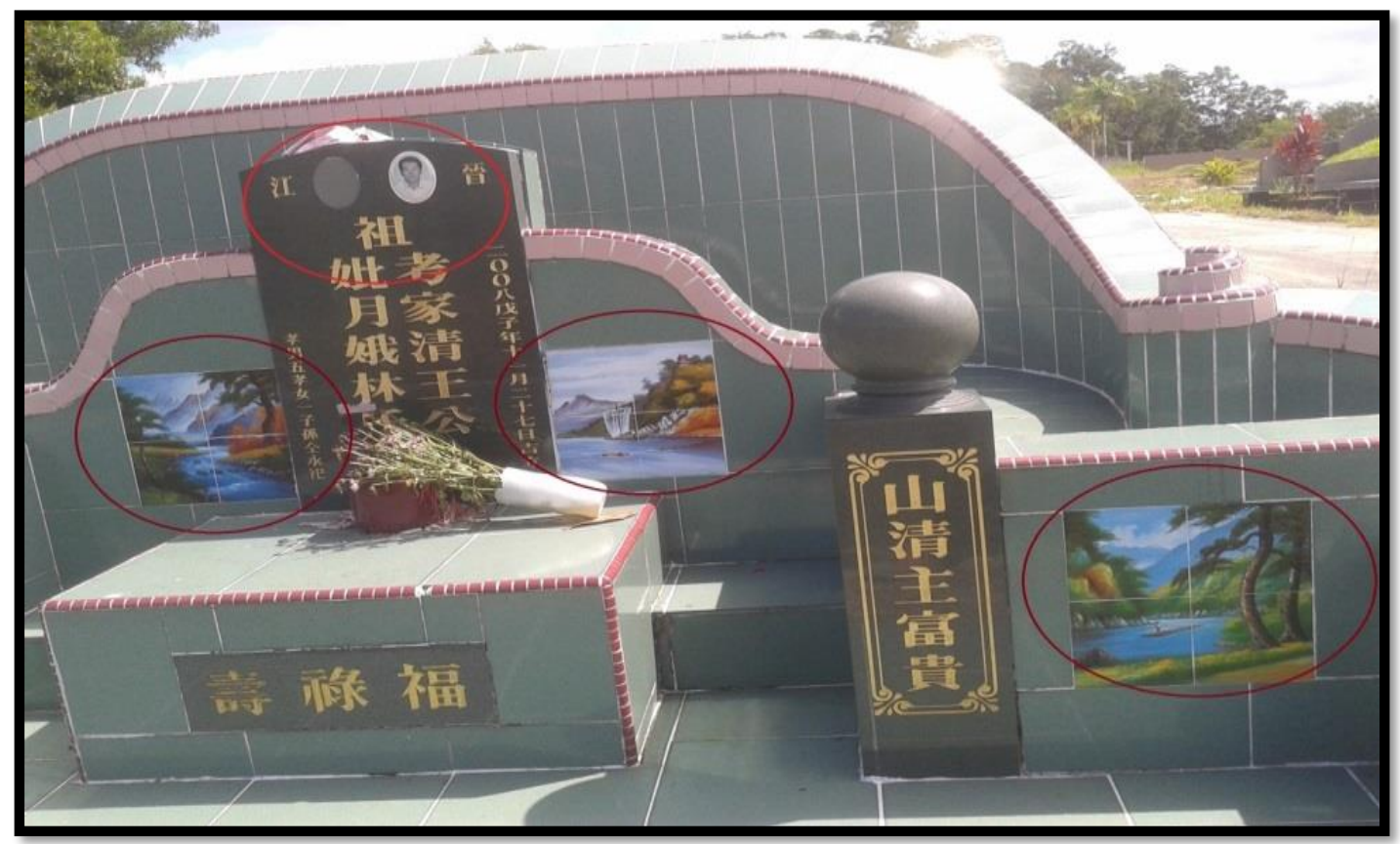

Figure 3. Different symbols at cemeteries. 
The style of decoration depends on their family. For example, the pictures above show the affordability of their family to decorate the grave lot. Some of them said that they believe the picture show the place their soul of their ancestor will go during their death transition. Furthermore, the pictures, of their ancestor to put at the grave also depends on the family to put it or not. This is because it is really costly and needs to be booked from Singapore.

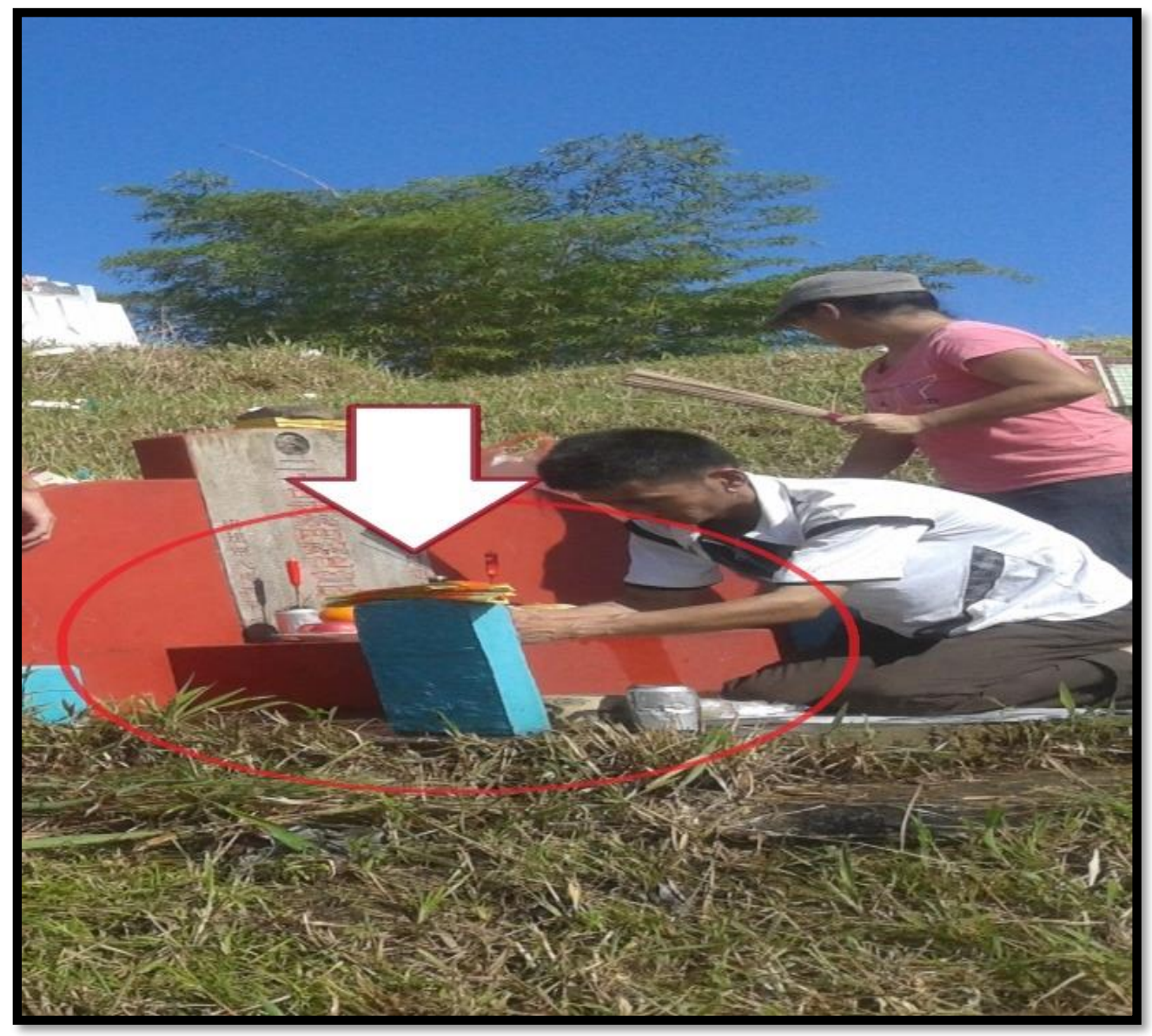

Figure 4. Blue colour stones.

The blue color stone in the picture above has the important function especially during Qing Ming festival. According to their story, it is used to call the guardians of their ancestor which is deity as a middle man to know the "wants" of their ancestor.

\section{Importance of Respecting The Dead}

It is really important to respect the dead. Even if the ancestor has passed away a long time ago, it is still important to visit them especially for Taoism they must go to the grave during the Qing Ming Festival that one time in a year. If they did not go there bringing the offering maybe the soul of the dead person will be angry with them because nobody comes to visit them.

\section{CONCLUSION}

According to our research, both beliefs are assimilating to each other. Furthermore, the young generation did not follow the entire custom in their religion and did not know much about it. This is maybe due to the mix marriages, lack of knowledge of new generation and increasing demands of economy.

\section{REFERENCES}

Briggs, Andrew Ryall, "Feng Shui and Chinese Rituals of Death across the Oregon Landscape" (2002). Geography Masters Research Papers. Pp.18. 
Dietrich, B. C. (1997). Death and afterlife in Minoan religion. Kernos. Revue internationale et pluridisciplinaire de religion grecque antique, (10), 19-38.

Fan, Y. I. (1956). Buddhism in China. Hong Kong: Union Press.

Hartz, P. R. (1993). Taoism World Religious. New York: Facts On File, Inc.

McDougall, C. (1956). Buddhism in Malaya. Singapore: Donald Moore.

Mong, L. S. (2006). Spectrum of Chinese Culture. Selangor: Pelanduk Publications (M) Sdn Bhd.

Palmer, M. (1991). The Elements of Taoism. Shaftesburry, Dorset: Element Books Limited.

San Filippo Ph, D. (2006). Religious Interpretations of Death, Afterlife \& NDEs.

Tan, C. B. (2011). Agama Cina di Malaysia: Satu Pandangan Umum. Jurnal Terjemahan Alam \& Tamadun Melayu, 2(2), $96-122$.

Tenney, C. D. (1908). Chinese History. The Washington Historical Quaterly, 2(2), 99-104. Retrieved April 27, 2016, from http://www.jstor.org/stable/40473852.

Wasmuth Jr, C. E. (1969). Concept of Death, The. Ohio St. LJ, 30, 32. 